\title{
Gamma Irradiation-Induced Preparation of Polyacrylonitrile Acrylamide Nano-Silica for Removal of Some Hazardous Metals
}

Mohamed Ragab Abass

Egyptian Atomic Energy Authority

Eman Elmasry ( $\square$ emanelmasry74@gmail.com )

Egyptian Atomic Energy Authority

Wafaa Mohamed El-Kenany

Egyptian Atomic Energy Authority

\section{Research Article}

Keywords: Gamma-irradiation, Polymerization, Nano-silica, Distribution Coefficients, Kinetic,

Thermodynamic.

Posted Date: August 19th, 2021

DOI: https://doi.org/10.21203/rs.3.rs-809665/v1

License: (c) (i) This work is licensed under a Creative Commons Attribution 4.0 International License. Read Full License

Version of Record: A version of this preprint was published at Journal of Inorganic and Organometallic Polymers and Materials on November 17th, 2021. See the published version at https://doi.org/10.1007/s10904-021-02156-1. 


\title{
Gamma irradiation-induced preparation of polyacrylonitrile acrylamide nano-silica for removal of some hazardous metals
}

Mohamed Ragab Abass, Eman Hassan EL-Masry* and Wafaa Mohamed El-Kenany Egyptian Atomic Energy Authority, Hot Laboratories, and Waste Management Center, 13759, Cairo, Egypt.

\begin{abstract}
Gamma-irradiation initiated polymerization was utilized to prepare polyacrylonitrile acrylamide nanosilica $\{\mathrm{P}(\mathrm{AN}-\mathrm{AM})-\mathrm{NS}\}$. Various analytical tools like XRD, FT-IR, SEM, TEM and DTA \& TGA were used to estimate the morphology, functional groups, and structure of $\{\mathrm{P}(\mathrm{AN}-\mathrm{AM})-\mathrm{NS}\}$ nanocomposite. The ability of $\{\mathrm{P}(\mathrm{AN}-\mathrm{AM})-\mathrm{NS}\}$ nanocomposite to remove $\mathrm{Cs}(\mathrm{I}), \mathrm{Pb}(\mathrm{II}), \mathrm{Cd}(\mathrm{II}), \mathrm{Sr}(\mathrm{II})$, and $\mathrm{Cu}(\mathrm{II})$ ions from the multi-component system was evaluated by batch techniques considering the influence of (shaking time, $\mathrm{pH}$, reaction temperatures), and capacity. At the optimum $\mathrm{pH}$, distribution coefficients have selectivity order; $\mathrm{Pb}^{2+}>\mathrm{Cs}^{+}>\mathrm{Cu}^{2+}>\mathrm{Cd}^{2+}>\mathrm{Sr}^{2+}$. The kinetic data obey pseudo-second-order models. The capacity was reduced by increasing the heating temperatures of solid powder. The thermodynamic parameters showed an endothermic and spontaneous. The investigation proved that $\{\mathrm{P}(\mathrm{AN}-\mathrm{AM})-\mathrm{NS}\}$ nanocomposite is a suitable organic-inorganic sorbent for the sorption of the studied ions from liquid solutions and could be considered as potential material for purification of effluent polluted with these ions.
\end{abstract}

Keywords: Gamma-irradiation. Polymerization. Nano-silica. Distribution Coefficients. Kinetic. Thermodynamic.

\section{Corresponding Author: E.H. EL-Masry}

emanelmasry74@gmail.com 
21 Introduction

3 Resin exchangers for environmental pollution remediation were widely used by different investigators

4 [1-3]. Many organic \& inorganic sorbents were reported with wide-ranging utility. Organic sorbents

5 have impoverished thermal and radiation stability and are therefore unstable in strong radiation fields at high temperatures [4]. Inorganic exchangers are very stable towards high radiation and temperatures but are inadequate to treat huge volumes of radwaste and costly [5]. Thus, to solve restrictions related to both organic \& inorganic sorbents, efforts were made for the combination of composite sorbents with enhanced properties [6]. Composite sorbents were produced by mixing polymers as supporting materials with inorganic species as an exchanger. The material is mechanically, thermally, and chemically more stable [7,8]. The polymer in composite material improves the mechanical, optical characteristics and provides more exchangeable spots [9]. The composite sorbents had a strong interest due to their variation of usages in unlike fields such as water purification, chemical separation, electrochemical sensor, solar cell, optical properties, and catalyst $[9,10]$. Many pollutants disrupt or change the chemical structure of water in the world and affect the aquatic environment [11]. The current methods for the sorption of hazardous metals from liquid waste solutions include chemical precipitation, ion exchange, membrane, adsorption, and biosorption [11]. Recently it is one of the biggest challenges to remove contaminants from wastewater, as their importance increases with growing industrial activities [2]. Studies on \% uptake of $\mathrm{Pb}(\mathrm{II}), \mathrm{Cs}(\mathrm{I}), \mathrm{Cu}(\mathrm{II}), \mathrm{Sr}(\mathrm{II}), \& \mathrm{Cd}(\mathrm{II})$ ions from liquid media have been focused largely on adsorption and ion exchange methods [12-14]. The potential toxicity and adverse health effects are shown by toxic metals such as $\mathrm{Cd}, \mathrm{Cu}, \mathrm{Pb}, \mathrm{Cs}$, and $\mathrm{Sr}$ ions.

In current work, polyacrylonitrile acrylamide nano-silica $\{\mathrm{P}(\mathrm{AN}-\mathrm{AM})-\mathrm{NS}\}$ was fabricated using the gamma radiation technique at $50 \mathrm{kGy}$. This material was characterized by utilizing various analytical tools. The main objective of the current work is to prepare nanocomposite and explore the efficiency of this nanocomposite towards the sorption of $\mathrm{Cs}(\mathrm{I}), \mathrm{Pb}(\mathrm{II}), \mathrm{Cu}(\mathrm{II}), \mathrm{Sr}(\mathrm{II}), \& \mathrm{Cd}(\mathrm{II})$ ions from liquid waste.

\section{$28 \quad 2.1$ Chemicals and reagents}

29 The main chemicals used to prepare $\{\mathrm{P}(\mathrm{AN}-\mathrm{AM})-\mathrm{NS}\}$ were $\mathrm{Na}_{2} \mathrm{SiO}_{3}$ (Loba Chemie, India), acrylonitrile 30 (AN), acrylamide (AM), N, N methylene bisacrylamide, and dimethyl ketone ( $\alpha$-Chemika, India). 31 Chemical such as $\mathrm{CsCl}, \mathrm{CuCl}_{2} \cdot 2 \mathrm{H}_{2} \mathrm{O}, \mathrm{SrCl}_{2}, \mathrm{PbCl}_{2}, \mathrm{CdCl}_{2}, \mathrm{AgNO}_{3}, \mathrm{HNO}_{3}$, and $\mathrm{HCl}$ (Merck, Germany) 
and $\mathrm{KOH}$ (El-Nasr, Egypt). Chemicals utilized in this article have an analytical assessment. For all tests, preparing (sample \& solutions) double-distilled water (DDW) was employed. Measurements of the initial $\mathrm{pH}$ of studied metal ion solutions were completed utilizing a lab pH-meter, (pH 601A, (USA).

\subsection{Gamma cell}

5 A Co ${ }^{60} \gamma$-cell of class MC-20 (Russia), was applied as a radiation foundation for the polymerization process at the Cyclotron, Egypt. The solution was irradiated in a plastic bottle. The irradiation dosage rate was $\sim 473.35 \mathrm{~Gy} / \mathrm{h}$.

\subsection{Preparation}

\subsubsection{Fabrication of nano-silica (NS)}

11 As reported [15], NS was fabricated by addition of concentrated $\mathrm{HCl}$ (dorpwith) to $\mathrm{Na}_{2} \mathrm{SiO}_{3}$ solution with constant stirring at $\left(25 \pm 1{ }^{\circ} \mathrm{C}\right)$ until $\mathrm{pH}$ approximately (8-9), gel of silica was obtained, and aged for one day, then decantation was carried out to separate the precipitate from the filtrate, accompanying washing with warm DDW sometimes until free from $\mathrm{Cl}^{-}$was tested using $\mathrm{AgNO}_{3}$ (dilute solution). After the drying at $80^{\circ} \mathrm{C}$, the NS powder collected, white NS were ground for $300 \mathrm{~s}$ in fast mills.

\subsubsection{Preparation of $\{\mathrm{P}(\mathrm{AN}-\mathrm{AM})-\mathrm{NS}\}$}

At $25 \pm 1{ }^{\circ} \mathrm{C}$ and constant stirring, add drop by drop of $10 \%$ (AN, AM \& NS) solutions and $0.1 \% \mathrm{~N}, \mathrm{~N}-$ methylene-bisacrylamide was developed for the production of $\{\mathrm{P}(\mathrm{AN}-\mathrm{AM})-\mathrm{NS}\}$ with volumetric ratios (AN: AM: NS) equal unity. The solution was agitated for $120 \mathrm{~min}$ to overcome complete homogeneity then subject to $\gamma$-irradiation within $50 \mathrm{kGy}$ of about 4.38 days. After the complete radiation process, gel yield was cut into minor wreckages, soaking in dimethyl ketone for the elimination of unreacted components, rinsed with DDW, dried at $60{ }^{\circ} \mathrm{C}$. The solid material was transformed into the hydrogen form by treating it for $24 \mathrm{~h}$ with $0.1 \mathrm{M} \mathrm{HNO}_{3}$. The gel product was purified numerous times with DDW to confiscate the excess $\mathrm{HNO}_{3}$ and dried at $60{ }^{\circ} \mathrm{C}$.

\subsection{Instruments}

The studied material was analyzed with an IR spectrophotometer (Alpha II Bruker, Germany). XRD measurement is conducted (Shimadzu, Japan). The prepared nanocomposite was analyzed for TGA\&DTA in $\mathrm{N}_{2}$ atmosphere by a (Shimadzu DTG-60 H). Direct observation via SEM examined the 
1 micrographs of the sample produced (model JSM-5400, JEOL Instrument, Japan). TEM was done using

2 (JEM2100, Jeol. s.b, Japan).

\section{$3 \quad 2.5$ Stability to different solvents}

4 The stability of $\{\mathrm{P}(\mathrm{AN}-\mathrm{AM})-\mathrm{NS}\}$ to chemical attack was conducted by shaking $100 \mathrm{mg}$ of 5 nanocomposite and $100 \mathrm{~mL}$ of DDW, $\mathrm{HNO}_{3}, \mathrm{HCl}$, and $\mathrm{KOH}$ in a range of concentrations [1-6 M]. The 6 solution with irregular shaking for about 4 days. The precipitate establish was detected gravimetrically 7 [14].

8

\section{$9 \quad 2.6$ Adsorption investigations}

\subsubsection{Influence of shaking time}

11 An equilibrium was done by shaking $0.1 \mathrm{~g}$ of solid in $\mathrm{H}^{+}$form with $10 \mathrm{~mL}$ of the multi-component system ( $\mathrm{Pb}(\mathrm{II}), \mathrm{Cs}(\mathrm{I}), \mathrm{Cu}(\mathrm{II}), \mathrm{Sr}(\mathrm{II})$, \& $\mathrm{Cd}(\mathrm{II})$ ions) in a shaker thermostat (Kottermann, Germany) at $25 \pm 1{ }^{\circ} \mathrm{C}$ with batch factor $(\mathrm{V} / \mathrm{m}=100 \mathrm{~mL} / \mathrm{g})$. After each time break, a shaker is fixed and the filtrate is removed at once from the solid. Hence, AAS was utilized to detect the tested ions concentration. The \% removal can be known by the next equation [16];

$$
\% \text { Removal }=\left(\frac{\mathrm{C}_{\mathrm{i}}-\mathrm{C}_{\mathrm{f}}}{\mathrm{C}_{\mathrm{i}}}\right) 100
$$

In which: $\mathrm{C}_{\mathrm{i}}$ (initial concentrations) \& $\mathrm{C}_{\mathrm{f}}$ (final concentrations) of metal ions in solution.

\subsubsection{Ion-exchange behavior}

To examine the sorption of the multi-component system (Cs(I), $\mathrm{Pb}(\mathrm{II}), \mathrm{Cu}(\mathrm{II}), \mathrm{Sr}(\mathrm{II}), \& \mathrm{Cd}(\mathrm{II})$ ions) using batch techniques, a sequence of experiments was applied at $100 \mathrm{mg} / \mathrm{L}$ for investigated cations at changed $\mathrm{pH}$ and $25 \pm 1^{\circ} \mathrm{C}$. Both distribution coefficient $\left(\mathrm{K}_{\mathrm{d}}\right)$ and separation factor $\left(\alpha_{\mathrm{b}}^{\mathrm{a}}\right)$ as a function of $\mathrm{pH}$ were calculated with the following equations [12]:

$$
\begin{aligned}
\mathrm{K}_{\mathrm{d}}(\mathrm{mL} / \mathrm{g}) & =\left(\frac{\mathrm{C}_{\mathrm{i}}-\mathrm{C}_{\mathrm{f}}}{\mathrm{C}_{\mathrm{f}}}\right) \frac{\mathrm{V}}{\mathrm{m}} \\
\alpha_{\mathrm{b}}^{\mathrm{a}} & =\frac{\mathrm{K}_{\mathrm{d}}(\mathrm{b})}{\mathrm{K}_{\mathrm{d}}(\mathrm{a})}
\end{aligned}
$$

where $\mathrm{V}$ and $\mathrm{m}$ are the solution volume $(\mathrm{L})$, and $\{\mathrm{P}(\mathrm{AN}-\mathrm{AM})-\mathrm{NS}\}$ weight $(\mathrm{g}), \mathrm{a} \& \mathrm{~b}$ are two competing types in a system. 
The kinetic analysis for the investigated cations onto the $\{\mathrm{P}(\mathrm{AN}-\mathrm{AM})-\mathrm{NS}\}$ in $\mathrm{H}^{+}$form was taken place by applying the solid with investigated cations $(100 \mathrm{mg} / \mathrm{L})$ with a $\mathrm{V} / \mathrm{m}$ ratio of $0.1 \mathrm{~L}^{-\mathrm{g}^{-1}}$ at the wanted $\mathrm{pH}$ in a shaker thermostat at $25 \pm 1^{\circ} \mathrm{C}$.

The influence of different reaction temperatures $\left(25-65^{\circ} \mathrm{C}\right)$ on the amount of sorbed ions $(\mathrm{q})$. In each experiment, $10 \mathrm{~mL}$ of investigated metal ions at the preferred $\mathrm{pH}$, and $0.1 \mathrm{~g}$ of solid in $\mathrm{H}^{+}$form was vigorously shacked for $4 \mathrm{~h}$ using a thermostatic water bath shaker. The solution's $\mathrm{pH}$ has been adjusted with $\mathrm{NaOH}$ and/or $\mathrm{HCl}$ for all investigations.

\subsubsection{Capacity measurements and thermal stability}

Batch equilibration repeated for investigated cations $(0.2 \mathrm{~g} / \mathrm{L})$ with the solid sorbent in $\mathrm{V} / \mathrm{m}=100 \mathrm{~mL} / \mathrm{g}$ was applied for the capacity estimation at different heating temperatures $\left(50-400^{\circ} \mathrm{C}\right)$ in a muffle kiln for $4 \mathrm{~h}$. The multi-component systems (Cs(I), $\mathrm{Pb}(\mathrm{II}), \mathrm{Cu}(\mathrm{II}), \mathrm{Sr}(\mathrm{II}), \& \mathrm{Cd}(\mathrm{II})$ ions) were agitated in a shaker thermostat at $\mathrm{pH}=4.3$ for $4 \mathrm{~h}$. The capacity was calculated from equation (4) $[17,18]$.

$$
\text { Capacity }=\Sigma \text { Uptake } \times \mathrm{C}_{\mathrm{i}} \times \frac{\mathrm{V}}{\mathrm{m}} \mathrm{mg} / \mathrm{g}
$$

\section{Results \& Discussion}

The object of this article is the effort to produce a great chemical stable organic-inorganic hybrid nanocomposite with a great affinity to $\mathrm{Pb}(\mathrm{II}), \mathrm{Cs}(\mathrm{I}), \mathrm{Cu}(\mathrm{II}), \mathrm{Sr}(\mathrm{II}), \& \mathrm{Cd}(\mathrm{II})$ cations from liquid solutions. Polyacrylonitrile acrylamide nano-silica was fabricated $\gamma$-irradiation within $50 \mathrm{kGy}$ with comprehensive characterization.

\subsection{Characterization}

\subsubsection{FT-IR}

IR spectrum of $\{\mathrm{P}(\mathrm{AN}-\mathrm{AM})-\mathrm{NS}\}$ nanocomposite (Fig. 1). This Figure shows that broadband was noticed at $3470-3300 \mathrm{~cm}^{-1}$ due to $\mathrm{H}_{2} \mathrm{O}$ (stretching vibration) and $\mathrm{OH}$ adsorbed on $\{\mathrm{P}(\mathrm{AN}-\mathrm{AM})-\mathrm{NS}\}$ [19]. Two bands were noticed at $3190 \& 2940 \mathrm{~cm}^{-1}$ due to $\mathrm{N}-\mathrm{H}$ (stretching vibration) \& $\mathrm{CH}_{2}$, respectively, [20-22]. A strong absorption band at $2244 \mathrm{~cm}^{-1}$ due to the $\mathrm{C} \equiv \mathrm{N}$ bond of $\mathrm{AN}$ (stretching vibration) [23]. 2 bands at $1661 \& 1605 \mathrm{~cm}^{-1}$, corresponding to amide I (stretching vibration) [24], and $\mathrm{N}-\mathrm{H}$ of $\mathrm{AM}$ (bending vibration) or $\mathrm{O}-\mathrm{H}$ bonded $\mathrm{H}_{2} \mathrm{O}$ absorbed on $\{\mathrm{P}(\mathrm{AN}-\mathrm{AM})-\mathrm{NS}\}$ [20,25]. The band appeared at $1571 \mathrm{~cm}^{-1}$ related to the C-N-H bond (bending vibration) [24]. 2 bands appeared at 1451 and $1413 \mathrm{~cm}^{-1}$ related to an asymmetric \& symmetric $\mathrm{CH}_{2}$ (bending vibration) [20,26]. 2 bands at 1340 and 
$11220 \mathrm{~cm}^{-1}$ related to asymmetric \& symmetric C-N (bending vibration) [24]. The bands appeared at $21040 \& 905 \mathrm{~cm}^{-1}$ attributed to Si-O-Si \& Si-O-H deformation vibration, respectively [27]. The bands at $3 \quad 636 \& 460 \mathrm{~cm}^{-1}$, attributed to $\mathrm{Si}-\mathrm{O}[19]$.

4

\subsubsection{XRD analysis}

$\mathrm{XRD}$ analysis of $\{\mathrm{P}(\mathrm{AN}-\mathrm{AM})-\mathrm{NS}\}$ (Figure 2). It is clear that the prepared material has a crystalline structure and this result was parallel to the data acquired from XRD of $\{\mathrm{P}(\mathrm{AM}-\mathrm{AA})-\mathrm{MgSi}\}$ [9] and (KCFC-PAN) [28]. It can be established that the unlike indexed peaks at 30.6, 45.1, and $77.7^{\circ}$ correspond to (031), (231), and (360) in \{P(AN-AM)-NS \} patterns (XRD JCPDS data file no. 43-1022) [9], a representative that it is supplemented with crystalline moieties. The motive for this is related to the presence of NS in $\{\mathrm{P}(\mathrm{AN}-\mathrm{AM})-\mathrm{NS}\}$. Another peak looking at $20.9^{\circ}$ corresponds to $(020)$ is crossbanding to the occurrence of AM [9].

\subsubsection{Thermal analysis}

DTA\&TGA chart of $\{\mathrm{P}(\mathrm{AN}-\mathrm{AM})-\mathrm{NS}\}$ (Fig. 3), via a three-steps. From 47 to $225{ }^{\circ} \mathrm{C}$ due to the reduction of surface moisture of polymeric resin [9], the weight loss is $10.5 \%$. From 225 to $505{ }^{\circ} \mathrm{C}$ due to the removal of $\mathrm{H}_{2} \mathrm{O}$ of crystallization [3] and complete decay of the organic portion of the powder [29], the lost weight is $33.2 \%$. From 505 to $700{ }^{\circ} \mathrm{C}$ due to heating in $\mathrm{N}_{2}$ consequences in a cyclization reaction with nitryl bonds converted to $\mathrm{C}=\mathrm{N}$ [29], the weight loss is $18.1 \%$. DTA displays that peak at $92{ }^{\circ} \mathrm{C}$ (endothermic) was attributed to the removal of surface moisture of polymeric resin. Two exothermic peaks appear at (353 and $533{ }^{\circ} \mathrm{C}$ ), respectively, corresponding to the widespread decomposition of the organic fragment or due to heating in $\mathrm{N}_{2}$ consequences in a cyclization reaction with nitryl bonds converted to $\mathrm{C}=\mathrm{N}$. From TGA data (Fig. 3), the lost weight is continuous up to $600{ }^{\circ} \mathrm{C}$. This supporting the fact that $\{\mathrm{P}(\mathrm{AN}-\mathrm{AM})-\mathrm{NS}\}$ has good thermal steadiness comparing with the different polymeric resins and the full lost weight with a heating temperature of $61.9 \%$.

\subsubsection{Morphology structures (SEM)}

Micrograph of $\{\mathrm{P}(\mathrm{AN}-\mathrm{AM})-\mathrm{NS}\}$ nanocomposite Figure (4A) showed an irregular, homogenous distribution of a large number of nanospheres spherical nanocomposite with the construction of a large number of cavities on the surface, which makes it easier to bring more active adsorption spots [22,23,30-32].

\subsubsection{TEM}


Transmission electron micrographs of $\{\mathrm{P}(\mathrm{AN}-\mathrm{AM})-\mathrm{NS}\}$ composite presented in Figure 4(B\&C), exposed the presence of spherical units with sizes ranged from 2.3 to $4 \mathrm{~nm}$. TEM images also showed no aggregations formation [33]. An experimentally noticed diffraction pattern viewing the central, intense, direct beam such a pattern, with a sharply intensive spot indicating that the specimen is at least moderately crystalline [34].

\subsection{Chemical stability}

The stability of $\{\mathrm{P}(\mathrm{AN}-\mathrm{AM})-\mathrm{NS}\}$ to chemical attack was studied in different solvents $\left(\mathrm{H}_{2} \mathrm{O}, \mathrm{HNO}_{3}\right.$, $\mathrm{HCl}, \& \mathrm{KOH})$ and the results are tabulated in Table (1) and indicated that the prepared sample is stable in $\mathrm{H}_{2} \mathrm{O}$ and $\left(\mathrm{HNO}_{3}\right.$ and $\left.\mathrm{HCl}\right)$ up to $3 \mathrm{M}$, whereas the solid is moderately dissolved at $4 \mathrm{M} \mathrm{HNO}_{3}$ and completely dissociated at $6 \mathrm{M}$, also the solid sample is stable in $\mathrm{KOH}$ up to $3 \mathrm{M}$, while partially dissociated at $4 \mathrm{M}$ and fully dissociated at $6 \mathrm{M}$. The \% solubility was raised by increasing of the acid \& base concentrations [14]. Also, these results reflect that the sequence of stability of the studied composite is $\mathrm{HCl}>\mathrm{HNO}_{3}>\mathrm{KOH}$.

\subsection{Sorption results}

\subsubsection{Distribution coefficients studies $\left(K_{d}\right)$}

Fig. 5A, illustrates the variation of $\mathrm{K}_{\mathrm{d}}$ of $\mathrm{Pb}^{2+}, \mathrm{Cs}^{+}, \mathrm{Cu}^{2+}, \mathrm{Sr}^{2+}$ and $\mathrm{Cd}^{2+}$ on $\{\mathrm{P}(\mathrm{AN}-\mathrm{AM})-\mathrm{NS}\}$, as a function of $\mathrm{pH}$. It is clear that the $\mathrm{K}_{\mathrm{d}}$ rise by the increase in $\mathrm{pH}$. The optimum $\mathrm{K}_{\mathrm{d}}$ was achieved at $\mathrm{pH} 4.3$ and was discovered to be (1655.6, 110.3, 91.7, 66.7, and 52.1 mL/g) for $\mathrm{Pb}(\mathrm{II}), \mathrm{Cs}(\mathrm{I}), \mathrm{Cu}(\mathrm{II}), \mathrm{Cd}(\mathrm{II})$, and $\mathrm{Sr}(\mathrm{II})$ ions, respectively. At a lower value $(\mathrm{pH} \leq 3), \mathrm{K}_{\mathrm{d}}$ was inhibited, related to the fact that when the $\mathrm{pH}$ is quite little, the existence of excess $\mathrm{H}^{+}$competes with $\mathrm{Pb}^{2+}, \mathrm{Cs}^{+}, \mathrm{Cu}^{2+}, \mathrm{Sr}^{2+}$ and $\mathrm{Cd}^{2+}$ in the liquor and preferably occupy the binding positions available in $\{\mathrm{P}(\mathrm{AN}-\mathrm{AM})-\mathrm{NS}\}[35,36]$. At a higher value $(\mathrm{pH}>3), \mathrm{K}_{\mathrm{d}}$ continuously rises with the increase in $\mathrm{pH}$ due to the reduction in $\mathrm{H}^{+}$competition and maximum uptake carried out at $\mathrm{pH}=4.3$ as well as uptake was slightly decreased at $\mathrm{pH}>4.3$, so all sorption experiments were done at $\mathrm{pH}$ 4.3. $\mathrm{K}_{\mathrm{d}}$ and $\alpha_{\mathrm{b}}^{\mathrm{a}}$ for the mentioned cations at several pHs (2.4-6) were calculated and tabulated in Table 2, and designated that the $\mathrm{K}_{\mathrm{d}}$ have the affinity arrangement; $\mathrm{Pb}^{2+}$ $>\mathrm{Cs}^{+}>\mathrm{Cu}^{2+}>\mathrm{Cd}^{2+}>\mathrm{Sr}^{2+}$, this arrangement supported that the sorption of studied cations was applied in hydrated ionic radii. The cations with minor hydrated ionic radii simply enter the cavities of the polymeric resin resulting in higher sorption [12]. $\alpha_{b}^{a}$ were computed and designated that $\mathrm{Pb}^{2+}$ has very greater $\alpha_{b}^{a}$ by $\left(31.8,24.8,18.1\right.$, and 15.0) for $\mathrm{Sr}^{2+}, \mathrm{Cd}^{2+}, \mathrm{Cu}^{2+}$, and $\mathrm{Cs}^{+}$at top uptake (pH 4.3), these 
values indicated that $\mathrm{Pb}$ (II) ions can simply separate from industrial and radioactive waste involved the above-mentioned cations.

Fig. 5B shows that the nonlinear relation between $\operatorname{logk} \mathrm{k}_{\mathrm{d}}$ and $\mathrm{pH}$ was observed for studied cations. This relation reflects the non-reality of the exchange mechanisms. This variation may be due to taking place reactions other than ion exchange, similar precipitation, and/or adsorption [14].

\subsubsection{Influence of shaking time}

Shaking time impact on the removal efficiency of $\mathrm{Pb}^{2+}, \mathrm{Cu}^{2+}, \mathrm{Sr}^{2+}, \mathrm{Cs}^{+}, \& \mathrm{Cd}^{2+}$ on $\{\mathrm{P}(\mathrm{AN}-\mathrm{AM})-\mathrm{NS}\}$ was done at $\mathrm{pH} 4.3$ and exposed in Fig. (6A). It can be understood that amount sorbed per unit gram of studied cations gradually increases with time and after $4 \mathrm{~h}$ the maximum removal of these ions was achieved and this time was used for further experimental work.

\subsubsection{Kinetic investigation}

The Lagergren pseudo-first-order (PFO) equation is stated as [2,13]:

$$
\log \left(q_{e}-q_{t}\right)=-\left(\frac{K_{f}}{2.303}\right) t+\log q_{e}
$$

In which $\mathrm{K}_{\mathrm{f}}\left(\mathrm{min}^{-1}\right)$ is a rate constant of PFO, $\mathrm{q}_{\mathrm{e}} \& \mathrm{q}_{\mathrm{t}}(\mathrm{mg} / \mathrm{g})$ are the amount sorbed per gram at equilibrium \& time t. Plotting $\log \left(\mathrm{q}_{\mathrm{e}}-\mathrm{q}_{\mathrm{t}}\right)$ beside $\mathrm{t}$ as exposed in Fig. (6B), the plot shows a linear relationship. The PFO suffered from lack when applied to $\mathrm{Pb}^{2+}, \mathrm{Cu}^{2+}, \mathrm{Sr}^{2+}, \mathrm{Cs}^{+}$, and $\mathrm{Cd}^{2+}$ sorption on the composite sorbent. When the $\mathrm{q}_{\mathrm{e}}$ achieved from Lagergren plots was associated with the $\mathrm{q}_{\mathrm{e}}$ (experimental) considered one of the main discrepancies was observed. Thus, good linearity of Lagergren plots is not promised that the reaction of $\mathrm{Pb}^{2+}, \mathrm{Cu}^{2+}, \mathrm{Sr}^{2+}, \mathrm{Cs}^{+}$, and $\mathrm{Cd}^{2+}$ with the sorbents don't follow PFO [37].

The pseudo-second-order (PSO) could be exemplified by the subsequent equation [38]:

$$
\frac{\mathrm{t}}{\mathrm{q}_{\mathrm{e}}}=\frac{1}{\mathrm{~K}_{\mathrm{s}} \mathrm{q}_{\mathrm{e}}^{2}}+\frac{\mathrm{t}}{\mathrm{q}_{\mathrm{e}}}
$$

where $\mathrm{K}_{\mathrm{s}}$ is PSO rate constant $\left(\mathrm{g} \mathrm{mg}^{-1} \mathrm{~min}^{-1}\right)$. Plots of $\mathrm{t} / \mathrm{q}_{\mathrm{t}}$ against $\mathrm{t}$ for $\mathrm{Pb}^{2+}, \mathrm{Cu}^{2+}, \mathrm{Sr}^{2+}, \mathrm{Cs}^{+}, \& \mathrm{Cd}^{2+}$ removal are exposed in Fig. (6C). A linear relationship is achieved and $\mathrm{R}^{2}$ nearer to unity and clarifies that the sorption procedure surveys PSO kinetics. The initial sorption rate represented as $h=K_{s}\left(q_{e}\right)^{2}, q_{e}$, $\mathrm{K}_{\mathrm{s}}$, \& $\mathrm{R}^{2}$ were computed and arranged in Table (3). These results reveal that $\mathrm{R}^{2}$ is nearer to unity for PSO than PFO. The $\mathrm{q}_{\mathrm{e}}$ is consistent with the $\mathrm{q}_{\mathrm{e}}$ (experimental). So, the sorption interaction can be approached more agreeably by the PSO. These data reveal that PSO is the chief interaction and $\mathrm{K}_{\mathrm{s}}$ of $\mathrm{Pb}^{2+}, \mathrm{Cu}^{2+}, \mathrm{Sr}^{2+}, \mathrm{Cs}^{+}$, and $\mathrm{Cd}^{2+}$ performs to be exact by the chemisorption method [38]. 


\subsubsection{Capacity measurements and thermal stability}

2 Heating temperatures affected the capacity of $\mathrm{Pb}^{2+}, \mathrm{Cu}^{2+}, \mathrm{Sr}^{2+}, \mathrm{Cs}^{+}$, and $\mathrm{Cd}^{2+}$ on $\{\mathrm{P}(\mathrm{AN}-\mathrm{AM})-\mathrm{NS}\}$ in $\mathrm{H}^{+}$ form was achieved, and the results were formulated in Table (4). The prominent reduction in the capacity was noticed with heating temperatures, corresponding to decay of the organic fragment of the solid as exposed in TGA\&DTA data [5]. The capacity increases according to reduction in the hydrated ionic radii \& hydration energy with sequence order; $\mathrm{Pb}^{2+}>\mathrm{Cs}^{+}>>\mathrm{Cu}^{2+}>\mathrm{Sr}^{2+}>\mathrm{Cd}^{2+}[39,40]$. The little capacity of this material for $\mathrm{Cd}^{2+}$ reflects the non-selectivity for this ion [14].

\subsubsection{Thermodynamic studies}

Fig. 7 displays the linear relation among $\operatorname{lnk}_{\mathrm{d}}$ of $\mathrm{Pb}^{2+}, \mathrm{Cs}^{+}, \mathrm{Cu}^{2+}, \mathrm{Sr}^{2+}$, and $\mathrm{Cd}^{2+}$ on $\{\mathrm{P}(\mathrm{AN}-\mathrm{AM})-\mathrm{NS}\}$ and 1000/T agreeing to the Van't Hoff equation [13];

$$
\ln \mathrm{K}_{\mathrm{d}}=\frac{\Delta \mathrm{S}^{\mathrm{o}}}{\mathrm{R}}-\frac{\Delta \mathrm{H}^{\mathrm{o}}}{\mathrm{RT}}
$$

where $\left(\Delta \mathrm{S}^{\circ}, \Delta \mathrm{H}^{\circ}, \mathrm{R}, \& \mathrm{~T}\right)$ are the change of entropy, the change of enthalpy, the gas constant, \& absolute temperature, respectively. $K_{d}$ of investigated cations improved with rising temperatures (298$338 \mathrm{~K}$ ) (i.e., the $\mathrm{K}_{\mathrm{d}}$ reduced with raising 1000/T) as exposed in Fig. 7. This enhancement in sorption was corresponding to the quickening of some firstly slow adsorption phases and the creation of some fresh exchangeable sites on the sorbent layers [13]. From the slopes \& intercepts displayed in Fig. 7, $\Delta \mathrm{H}^{\circ}$ \& $\Delta \mathrm{S}^{\circ}$ were assessed and arranged in Table (5). +ve values of both $\Delta \mathrm{H}^{\circ} \& \Delta \mathrm{S}^{\circ}$ indicate the endothermic nature of the sorption process and bigger randomness of solid solution interface in the adsorption of these cations on $\{\mathrm{P}(\mathrm{AN}-\mathrm{AM})-\mathrm{NS}\}$, respectively [13].

The change of free energy $\Delta \mathrm{G}^{\circ}$ was computed by the equation:

$$
\begin{aligned}
& \Delta \mathrm{G}^{\mathrm{o}}=\Delta \mathrm{H}^{\mathrm{o}}-\mathrm{T} \Delta \mathrm{S}^{\mathrm{o}} \\
& \Delta \mathrm{G}^{\mathrm{o}}=\mathrm{TR} \ln \mathrm{K}_{\mathrm{d}}
\end{aligned}
$$

-ve values of $\Delta \mathrm{G}^{\circ}$ represented in Table (5) reflect that the sorption is spontaneous and reveal the better sorption of these ions on $\{\mathrm{P}(\mathrm{AN}-\mathrm{AM})-\mathrm{NS}\}$ compared with $\mathrm{H}^{+}$ion [13].

\section{Conclusion:}

Polyacrylonitrile acrylamide nano-silica was fabricated, characterized, and employed for batch sorption of lead, cesium, copper, strontium, and cadmium ions from an liquid medium. \{P(AN-AM)-NS \} fabricated by $\gamma$-radiation initiated preparation at $50 \mathrm{kGy}$. The distribution coefficients at optimum $\mathrm{pH}$ have selectivity order: $\mathrm{Pb}^{2+}>\mathrm{Cs}^{+}>\mathrm{Cu}^{2+}>\mathrm{Cd}^{2+}>\mathrm{Sr}^{2+}$. The systems kinetic follow pseudo-second-order 
kinetics. The capacity of studied cations reveals that $\{\mathrm{P}(\mathrm{AN}-\mathrm{AM})-\mathrm{NS}\}$ has affinity sequence; $\mathrm{Pb}^{2+}>\mathrm{Cs}^{+}$ $\gg \mathrm{Cu}^{2+}>\mathrm{Sr}^{2+}>\mathrm{Cd}^{2+}$. Finally, thermodynamic parameters showed that the sorption interaction was spontaneous \& endothermic.

Acknowledgments: This work has been supported by the Egyptian Atomic Energy Authority. Great thanks to all members of the nuclear fuel technology department, Egyptian Atomic Energy Authority for supporting this work.

\section{References}

1. V. K. Gupta, S. Agarwal, D. Pathania, N. C. Kothiyal, and G. Sharma, Carbohydrate Polymers 96, 277 (2013).

2. M. R. Abass, E. H. El-Masry, and A. B. Ibrahim, Environmental Geochemistry and Health 43, 3169 (2021).

3. M. R. Abass, A. B. Ibrahim, and M. M. Abou-Mesalam, Chemical Papers 75, 3751 (2021).

4. D. Pathania, G. Sharma, A. Kumar, and N. C. Kothiyal, Journal of Alloys and Compounds 588, 668 (2014).

5. V. K. Gupta, S. Agarwal, I. Tyagi, D. Pathania, B. S. Rathore, and G. Sharma, Ionics 21, 2069 (2015). 6. V. K. Gupta, G. Sharma, D. Pathania, and N. C. Kothiyal, Journal of Industrial and Engineering Chemistry 21, 957 (2015).

7. D. Pathania, G. Sharma, M. Naushad, and V. Priya, Desalination and Water Treatment 57, 468 (2016).

8. A. A. Khan and L. Paquiza, Desalination 265, 242 (2011).

9. M. M. Abou-Mesalam, M. R. Abass, A. B. Ibrahim, A. M. Elseman, and A. M. Hassan, Bulletin of Materials Science 42, 31 (2019).

10. B. J. Sanghavi, S. M. Mobin, P. Mathur, G. K. Lahiri, and A. K. Srivastava, Biosensors and Bioelectronics 39, 124 (2013).

11. R. F. Aglan and M. M. Hamed, Russian Journal of Applied Chemistry 87, 373 (2014).

12. M. M. Abou-Mesalam, M. R. Abass, A. B. Ibrahim, and E. S. Zakaria, Desalination and Water Treatment 193, 402 (2020).

13. E. A. Abdel-Galil, A. B. Ibrahim, and M. M. Abou-Mesalam, International Journal of Industrial Chemistry 7, 231 (2016).

14. M. M. Abou-Mesalam, M. R. Abass, M. A. Abdel-Wahab, E. S. Zakaria, and A. M. Hassan, Desalination and Water Treatment 109, 176 (2018).

15. H. El-Didamony, E. El-Fadaly, A. A. Amer, and I. H. Abazeed, Boletín de La Sociedad Española de Cerámica y Vidrio 59, 31 (2020).

16. M. M. Hamed, A. M. Shahr El-Din, and E. A. Abdel-Galil, Journal of Radioanalytical and Nuclear Chemistry 322, 663 (2019).

17. M. M. Hamed, S. E. Rizk, and A. A. Nayl, Particulate Science and Technology 34, 716 (2016).

18. M. M. Abass, A. B. Ibrahim, E. H. El-Masry, and M. M. Abou-Mesalam, Journal of Radioanalytical and Nuclear Chemistry 329, 849 (2021).

19. M. R. Abass, H. M. Diab, and M. M. Abou-Mesalam, Silicon 1 (2021).

20. S. Lee, J. Kim, B.-C. Ku, J. Kim, and H.-I. Joh, Advances in Chemical Engineering and Science 02, 
275 (2012).

21. M. Afifi, M. R. Abass, H. M. Diab, M. M. Abou-Mesalam, and M. S. Gaafar, Silicon 1 (2021).

22. W. Zhu, Z. Yang, A. Yasin, Y. Liu, and L. Zhang, Materials 14, 3277 (2021).

23. Q. Zhao and T. Cao, Industrial \& Engineering Chemistry Research 51, 4952 (2012).

24. A. S. Dawood and Y. Li, Polish Journal of Environmental Studies 23, 43 (2014).

25. M. M. Abou-Mesalam, M. R. Abass, M. A. Abdel-Wahab, E. S. Zakaria, A. M. Hassan, and H. F. Khalil, Desalination and Water Treatment 57, 25757 (2016).

26. M. F. Hassan and S. Z. M. Yusof, Microscopy Research 2, 30 (2014).

27. E. H. Borai, M. G. Hamed, A. M. El-Kamash, T. Siyam, and G. O. El-Sayed, New Journal of Chemistry 39, 7409 (2015).

28. A. Nilchi, A. Khanchi, H. Atashi, A. Bagheri, and L. Nematollahi, Journal of Hazardous Materials 137, 1271 (2006).

29. Y. F. El-Aryan, E. A. Abdel-Galil, and G. E. S. El-deen, Russian Journal of Applied Chemistry 88, $516(2015)$.

30. K. M. Abualnaja, A. E. Alprol, M. A. Abu-Saied, A. T. Mansour, and M. Ashour, Nanomaterials 11, 1144 (2021).

31. P. Bhardwaj, S. Singh, V. Singh, S. Aggarwal, and U. K. Mandal, International Journal of Polymeric Materials 57, 404 (2008).

32. S. N. A. M. Jamil, M. Khairuddin, and R. Daik, E-Polymers 15, 45 (2015).

33. W. P. S. L. Wijesinghe, M. Mantilaka, T. Karunarathne, and R. M. G. Rajapakse, Nanoscale Advances 1, 86 (2019).

34. B. A. Carter, D. B. Williams, C. B. Carter, and D. B. Williams, Transmission Electron Microscopy: A Textbook for Materials Science. Diffraction. II (Springer Science \& Business Media, 1996).

35. S. S. Metwally, H. S. Hassan, and N. M. Samy, Journal of Molecular Liquids 287, 110941 (2019).

36. E. A. Abdel-Galil, A. B. Ibrahim, and W. M. El-Kenany, Desalination and Water Treatment 1 (2021).

37. R. R. Sheha and A. A. El-Zahhar, Journal of Hazardous Materials 150, 795 (2008).

38. E. H. Borai, M. F. Attallah, A. H. Elgazzar, and A. S. El-Tabl, Particulate Science and Technology 37, 414 (2019).

39. N. Rahman, U. Haseen, and M. Rashid, Arabian Journal of Chemistry 10, S1765 (2017).

40. A. P. Gupta, H. Agarwal, and S. Ikram, Journal of the Indian Chemical Society 80, 57 (2003). 
Figures

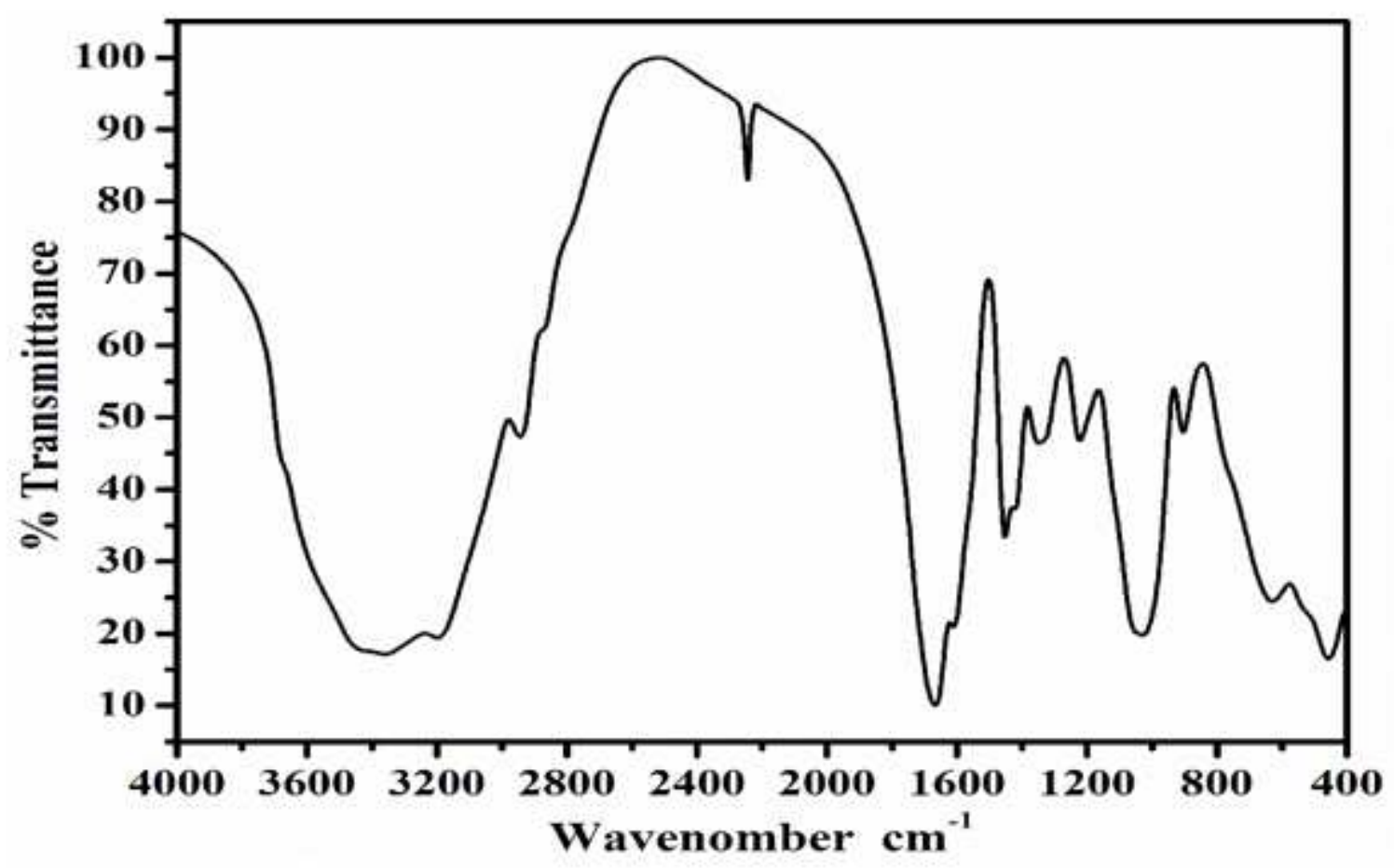

Fig. 1.

Figure 1

IR spectra for $\{\mathrm{P}(\mathrm{AN}-\mathrm{AM})-\mathrm{NS}\}$ nanocomposite. 


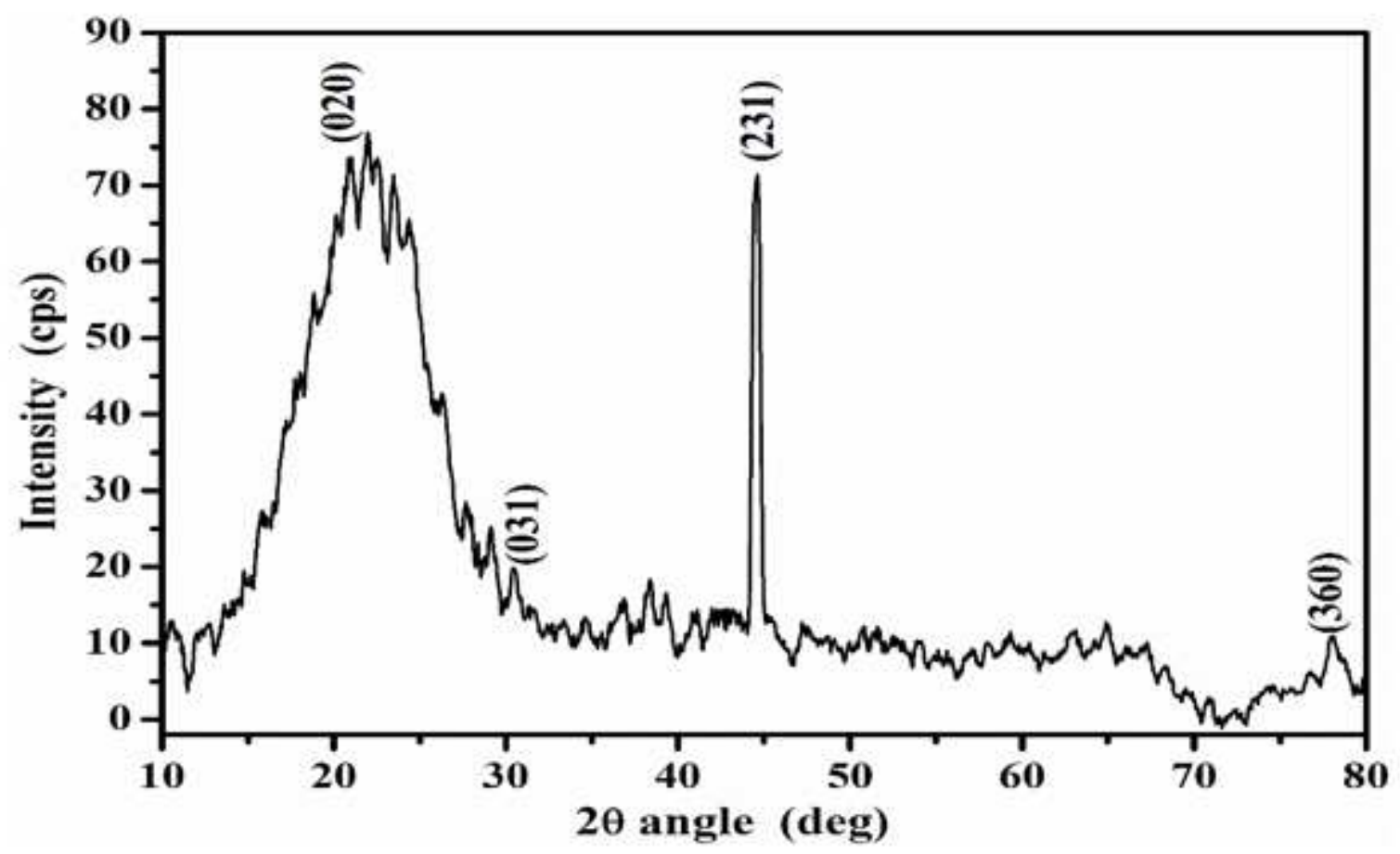

Fig. 2.

Figure 2

XRD analysis for $\{\mathrm{P}(\mathrm{AN}-\mathrm{AM})-\mathrm{NS}\}$ nanocomposite. 


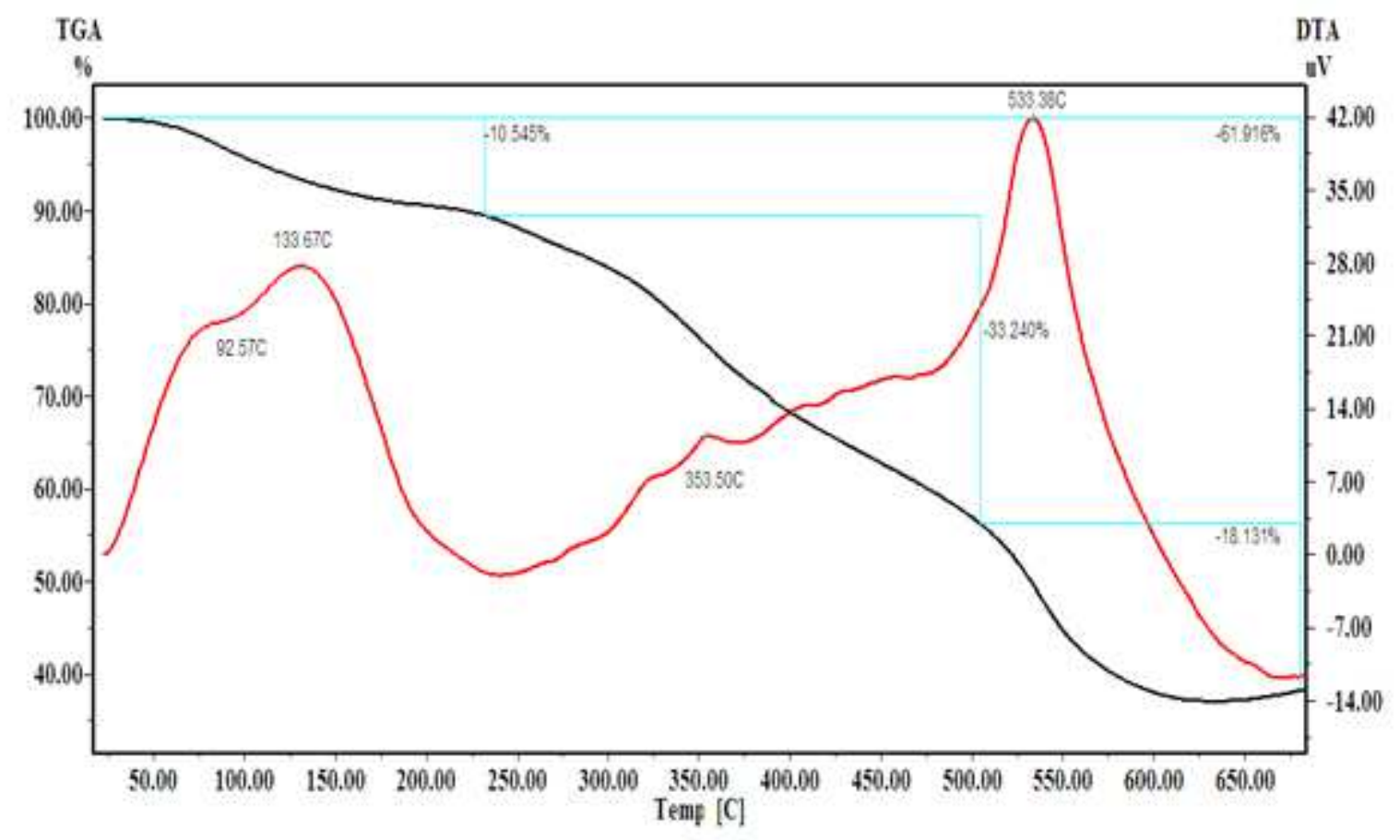

Fig. 3.

Figure 3

TGA \& DTA analysis for $\{$ P(AN-AM)-NS $\}$ nanocomposite. 

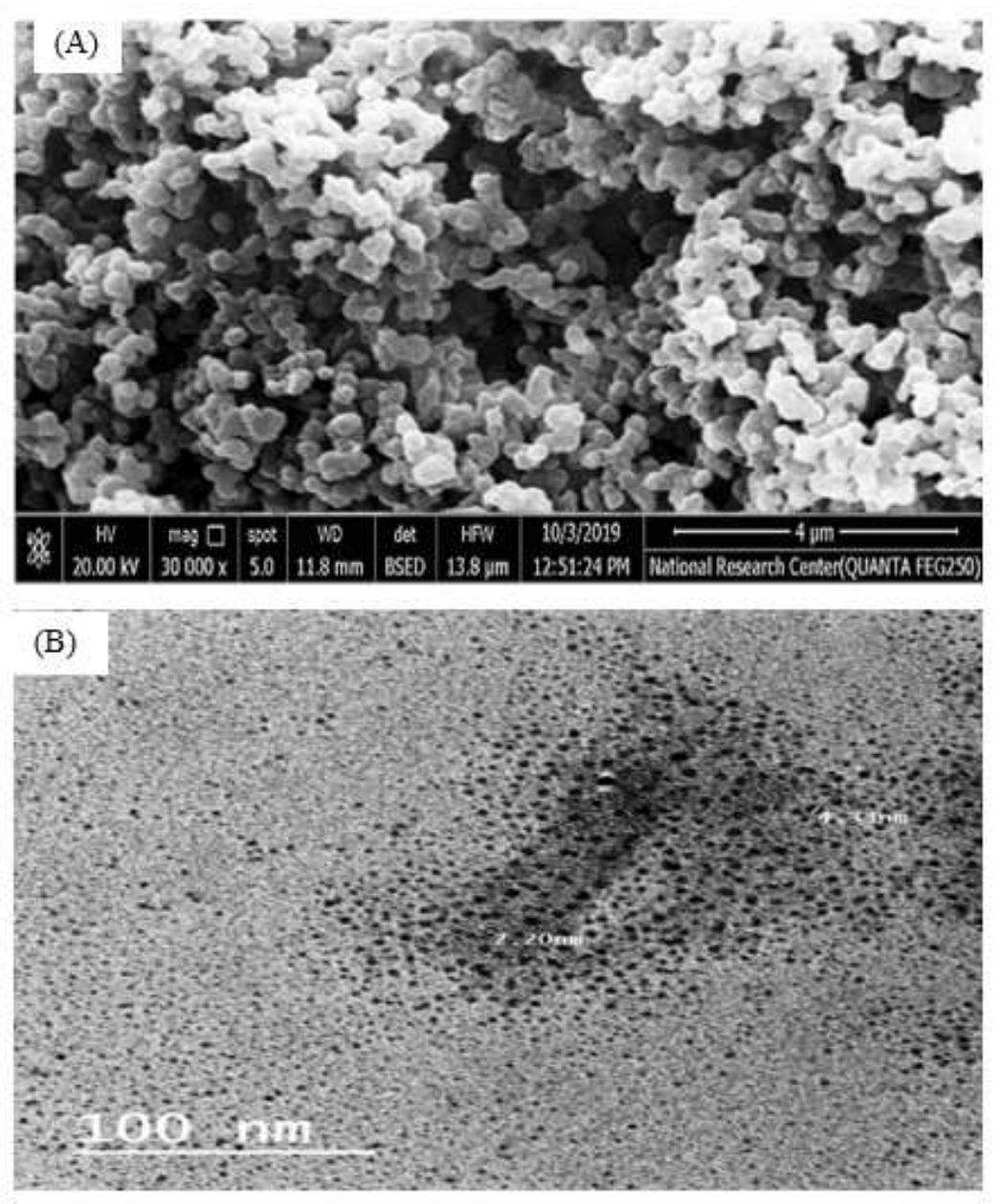

\section{(C)}

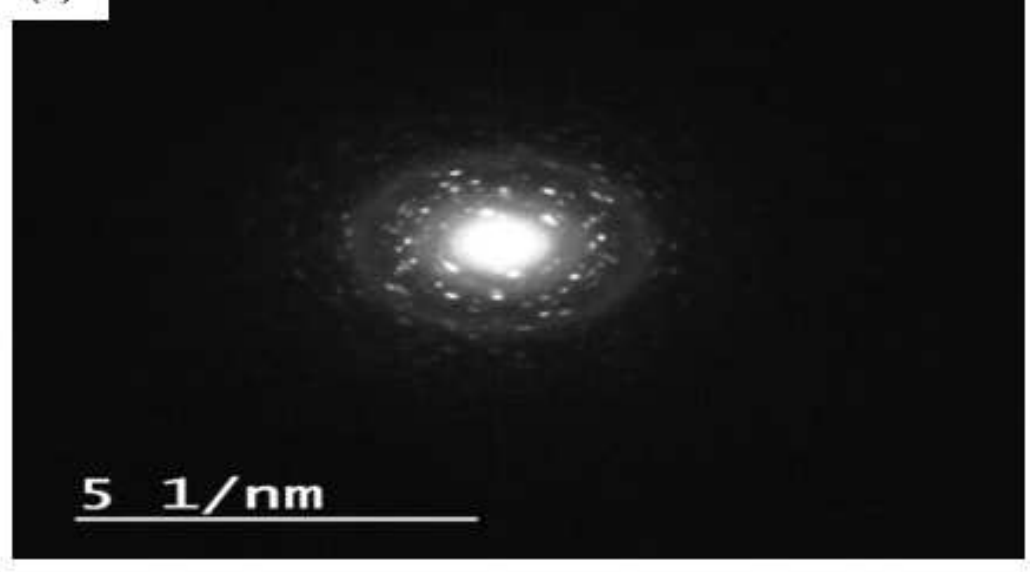

Fig. 4.

Figure 4

(A) SEM micrograph (B) and (C) TEM images of $\{P(A N-A M)-N S\}$ nanocomposite. 

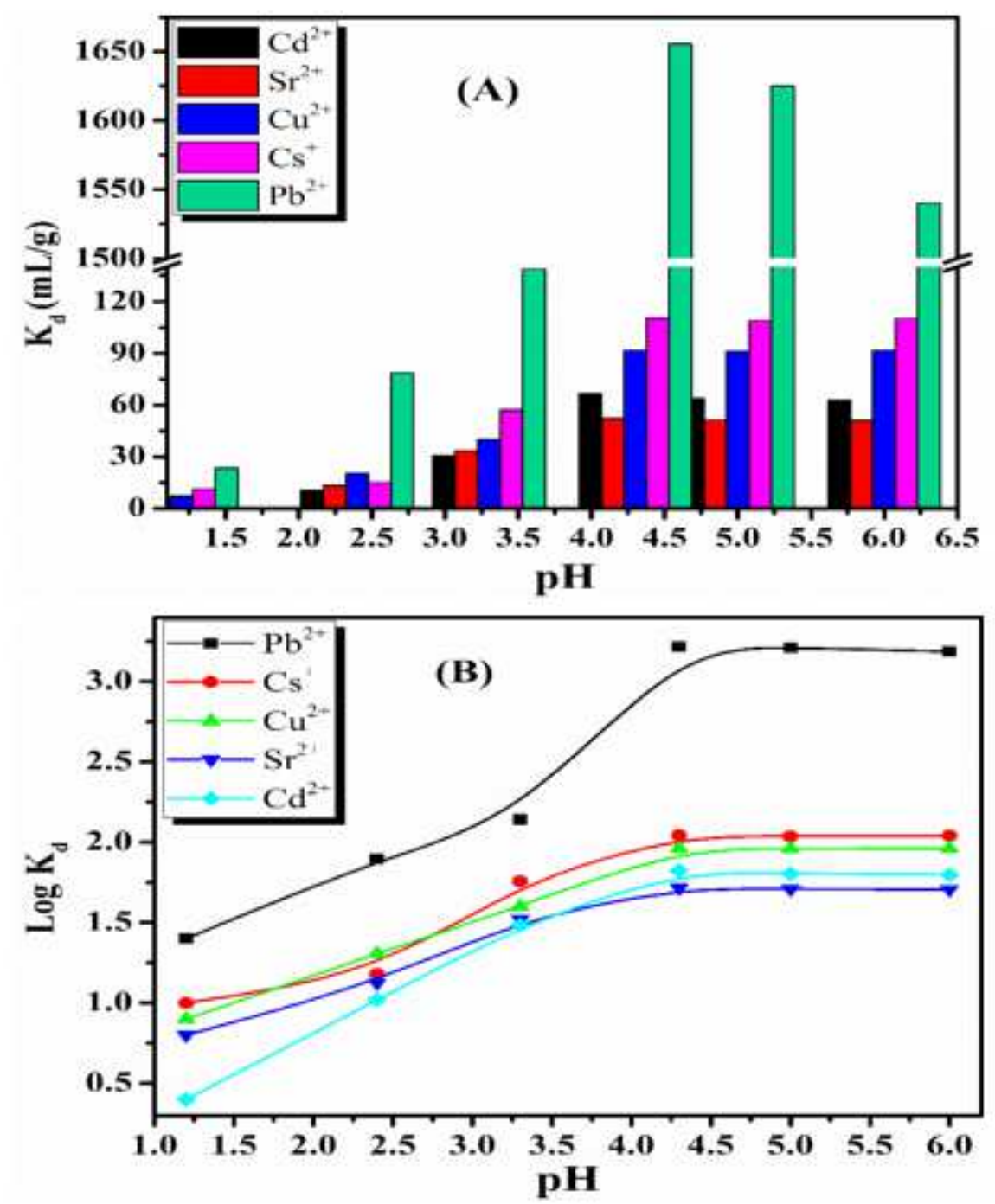

Fig. 5.

Figure 5

Sorption behavior of various metal ions onto $\{\mathrm{P}(\mathrm{AN}-\mathrm{AM})-\mathrm{NS}\}$ at $25 \pm 1^{\circ} \mathrm{C}$, (A) Effect of $\mathrm{pH}$ on $\mathrm{Kd}(\mathrm{B}) \mathrm{Plots}$ of log Kd against $\mathrm{pH}$. 

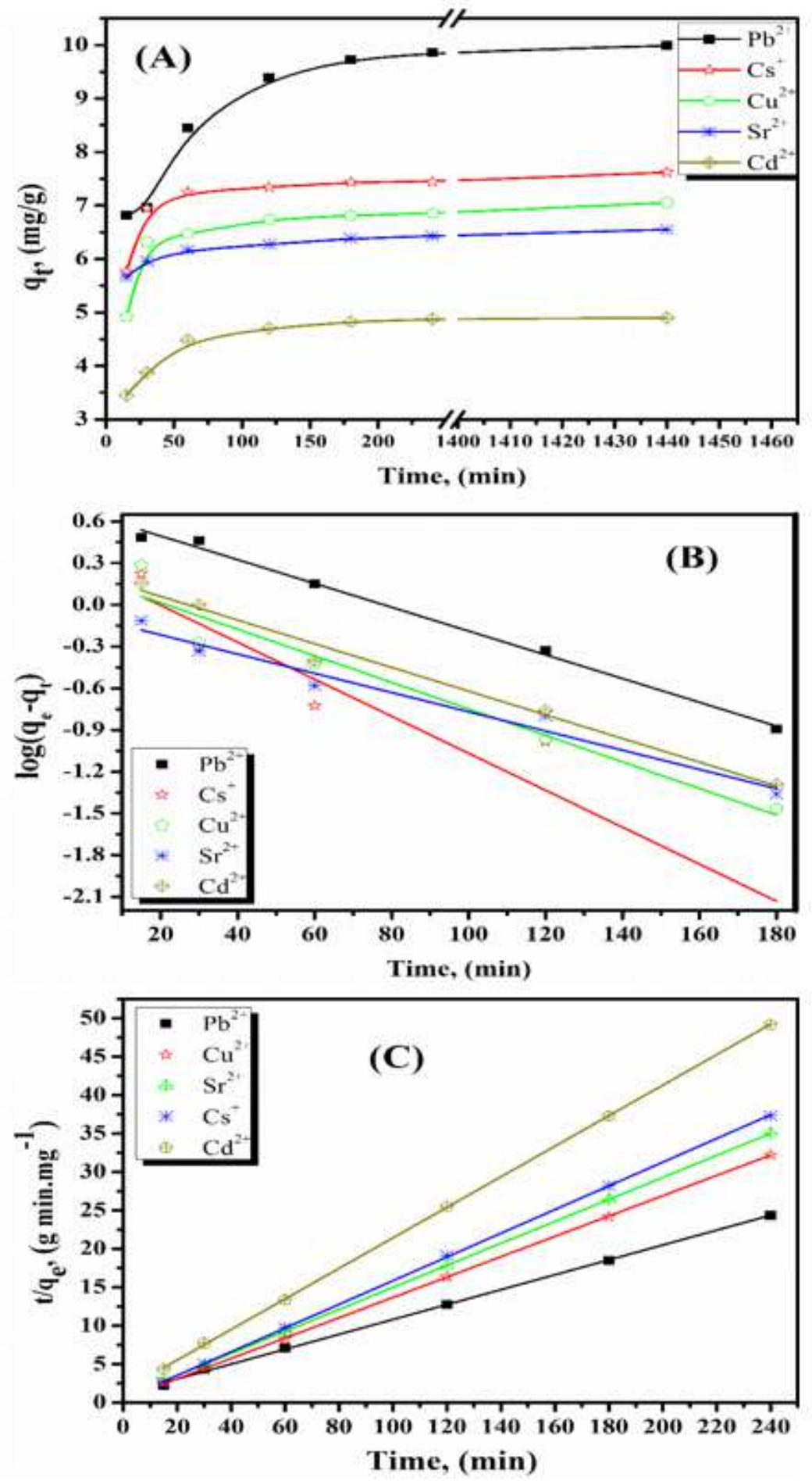

Fig. 6.

\section{Figure 6}

Sorption of various metal ions on $\{\mathrm{P}(\mathrm{AN}-\mathrm{AM})-\mathrm{NS}\}$ at $25 \pm 1{ }^{\circ} \mathrm{C}(\mathrm{A})$ Effect of contact time on the amount sorbed, (B) Pseudo first-order kinetic plots, and (C) Pseudo second-order kinetic plots. 


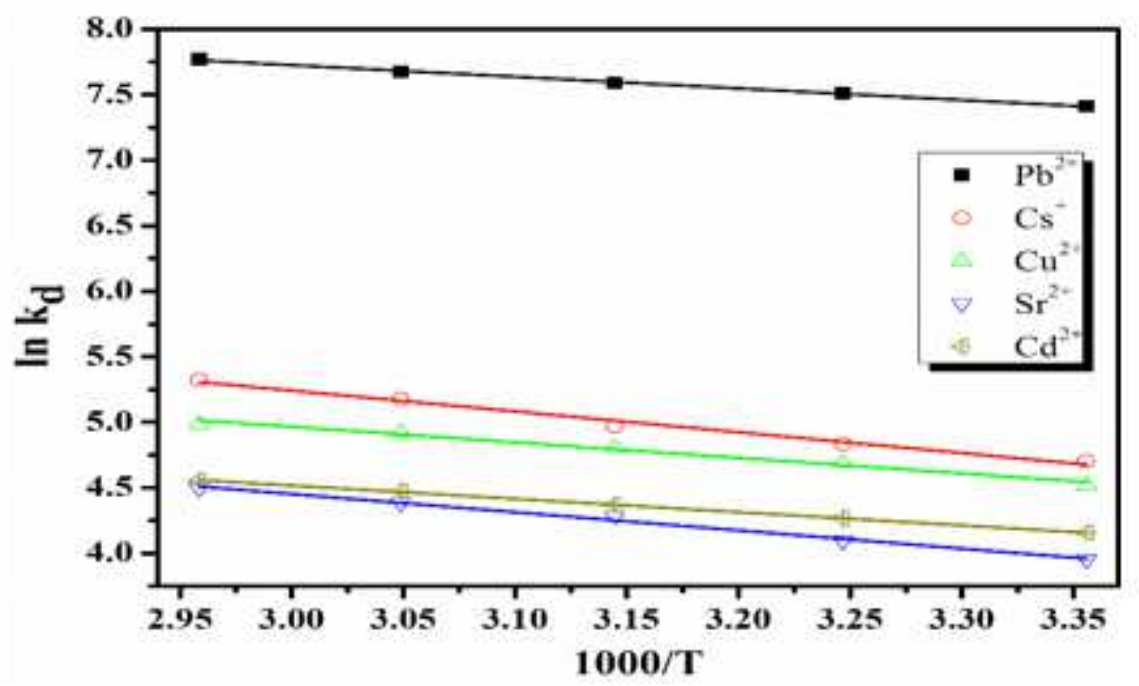

Fig. 7.

Figure 7

Van't Hoff plot of the adsorption of various metal ions on $\{$ P(AN-AM)-NS\}.

\section{Supplementary Files}

This is a list of supplementary files associated with this preprint. Click to download.

- GraphicalAbstract.docx

- Highlights.docx

- Tables.pdf

- DeclarationofInterestStatement.docx 